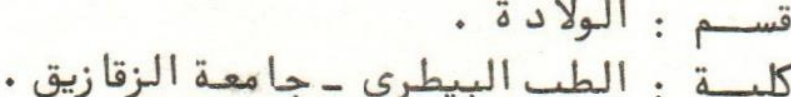

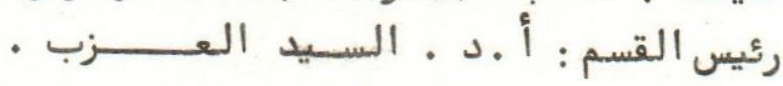

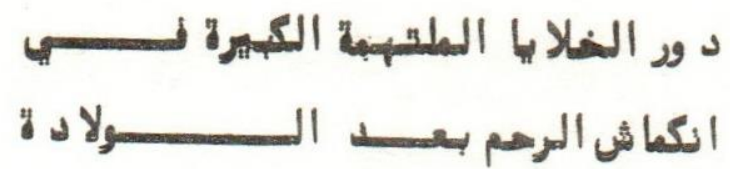

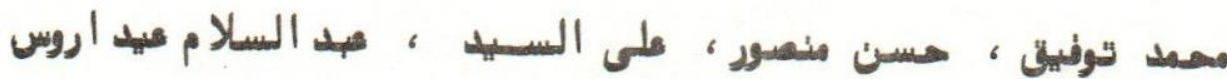

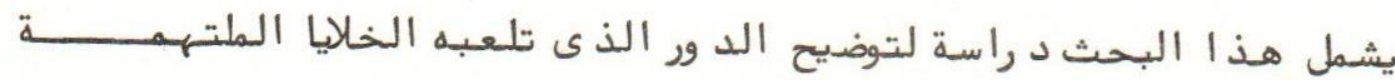

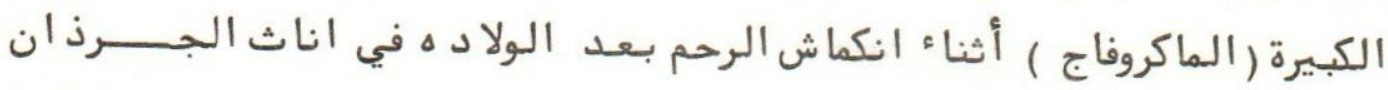

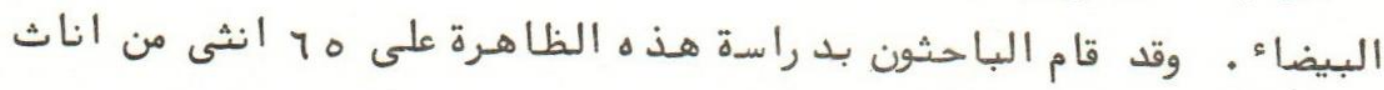

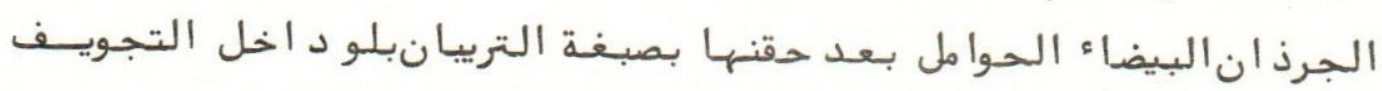

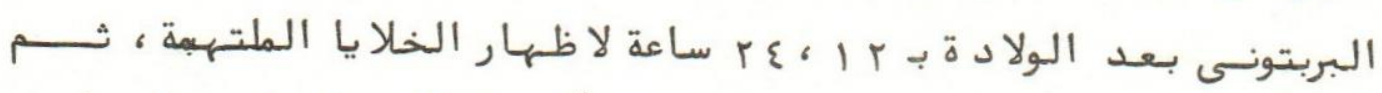

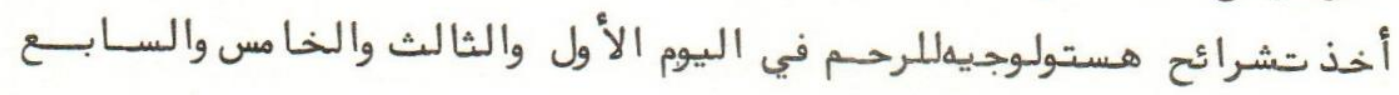
والتاســعـع

وقد أظهر البحث في اليوم الأول تواجد الخلا يا الملتههنهة في مجاميع د اخل

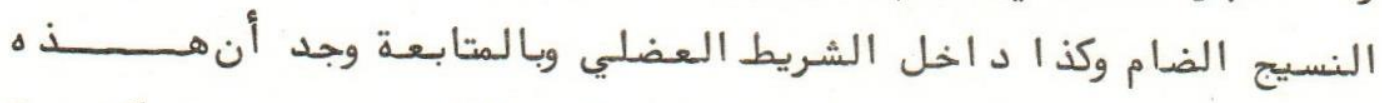

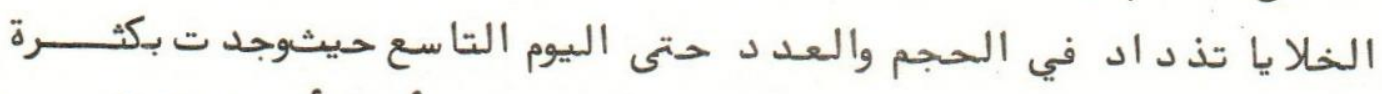
وخاصة في عضلات الرحم والرباط الجانبي وقد وجد أيضا أن النقط الد هـية أنسية

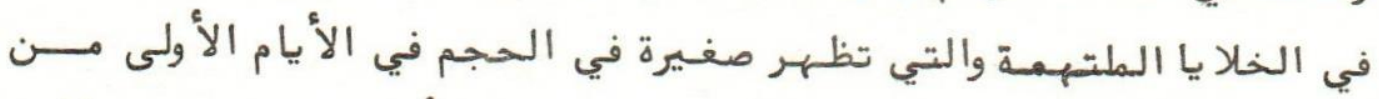

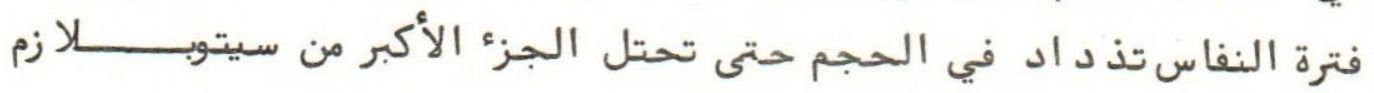
الخليه مما يوءدى الى تحريك نواه الخليه جانبا . ومن هـذا يمكن استتناج أن الخلايا المتلهيمه لها د ور أساسي في انكمـاش الرحم بعـد الرولاد هُ وخاصة في منطقة الرباط الجانبي حيث توجد الأوعيــة 
Dept. Of Obstetrics, Gynaecology \& A.I.,

Fac. of Vet. Med., Zagazig University, Zagazig, Egypt.

Head of Dept. Prof. Dr. E.A. El-Azab.

\title{
THE INVOLVEMENT OF MACROPHAGES IN THE UTERINE INVOLUTION
} (With 3 Figures)

\author{
By \\ M.T. NASR; H.MANSOUR; A. ABDEL RAHEIM and A. EIDAROOS \\ (Received at 29/6/1982)
}

\begin{abstract}
SUMMARY
A study was done to demonstrate the role played by macrophages in the process of uterine involution in female rats. Sixty five pregnant female rats were the materials of this investigation. After parturition by 12 and 24 hours the rats were intraperitonially injected with trypan blue to demonstrate the macrophages. Histological sections were taken at 1, 3, 5, 7 and 9 days after parturition. At the first day post-partum, the macrophages were found in groups in C.T. and between the muscle bundles. At the 3rd day, they increase in number and size up to the 9th day where they were observed in abundance specially in the myometrium and at the site of the ligamontum latum. In addition their fat droplets which appeared small in size in the early post-partum period became bigger by time up to the 9th day where they occupied the main cytoplasm leading the nucleus to be shifted aside. It could be concluded that the macrophages played a great role in the process of involution of the uterus. Moreover, the main regression occured in the region of the ligamentum latum due to the presence of B.Vs. and abundant number of macrophages.
\end{abstract}

\section{INTRODUCTION}

It was thought that the macrophages and other cells played great role in the process of involution of the uterus. The uterine involution takes place through the hypotrophy of the uterine smooth muscle fibres, collagen resorption and rapid breakdown of muscle proteins together with the connective tissue framework of the uterus (WOESSNER and BREWER, 1963). PARAKKAL (1969) in a study on the mouse uterine involution by light and electron microscopy, observed numerous cells, identifiable as macrophages; because of their ability to take up the vital stain; in the C.T. of both myometrium and endometrium. Moreover, the number of macrophages in the involuting uteri increased significantly soon after parturition. Numerous lipid droplets were demonstrated by oil red 0 characterized the macrophages of the involuting uterus. By the electron microscope, the later author found that, as the macrophages became actively phagocytic, the entire cell was filled with vacoules that contained collagen fibres undergoing degeneration. LOBEL and DEANE (1962) demonstrated that the macrophages of the involuting rat uterus showed marked reaction for acid phosphatase and lipid droplets in its cytoplams. DESSOUKY (1971) studied the myometrial changes in the post-partum uterine involution of the guinea pigs. He found that the cells which have the characteristics of macrophages increased gradually in number and size and spread between the smooth muscle cells. Vesicular and dense bodies lysosomes appeared early in their cytoplasm. Concurrently, collagenous fibrils either free or membrane bound were also seen in these cells. Later, phagolysosomal

Assiut Vet. Med. J. Vol. 12, No. 24, 1984. 
structures and collagenous fibrils in various stages of degradation occupied a large area of cytoplasm.

The aim of the present study is to demonstrate the role of the macrophages in the process of uterine involution.

\section{MATERIALS and METHODS}

Sixty five female rats ranging in age from 4 to 8 months and varying from $175-270$ gm. were used for this investigation. The rats lived in boxes at room temperature $\left(22^{\circ} \mathrm{C}\right)$ in light-darkness interval of 12 hours, and given feed and enough water supply. The male rat was left with the females at the day of oestrus.

Directly, 12 and 24 hours after parturition, 50 female rats were injected intra peritoneally with $2-3 \mathrm{ml}$. of $0.5 \%$ trypan blue in sterile saline solution $(1 \mathrm{ml} / 100 \mathrm{gm}$. B.B.) to demonstrate the macrophages. The control rats (15) were left without injection of the dye.

At 1, 3, 5, 6 and 9 days after parturition, 10 rats were killed. The uteri were prepared and fixed in Bouin's solution. For histological preparations, the uterus stock was cut into parts, one half of it passed in an ascending alcohol series, embeded in paraffin, then sectioned with Leitz microtome into about 5 microns thick sections. The sections were dried in an autoclave at $42-45{ }^{\circ} \mathrm{C}$. For the demonstration of the vital stain the sections were stained with $H$ \& $E$ as a background. Other sections were stained with trichrome stain to demonstrate the C.T. The other stock which was cut into about 10 microns thick sections and stained with oil red $D$ stain for the emonstration of fats.

\section{RESULTS}

The histological examinstion of the uterine sections as illustrated in figures, 1,2 and 3 demonstrated that at the 1st day post-partum the macrophages appeared small with relative large nucleus.

More macrophages found in groups in the C.T., as well as between the muscule bundles. These cells exhibited the trypan blue stain substance in its cytoplasm. With the oil red 0 stain these cells show small fat droplets in its cytoplasm. A lot of C.T. elements appeared with the trichrome stain surrounding the muscle bundles and B. Vs.

Around the B. Vs. of ligamentum latum (the site of connection of the placenta to the uterine wall) and in between the muscles, there were numerous swollen cells stained with $H$ \& E, exhibiting eosinophilic granules.

At the 3rd. day post-partum, the macrophages increased in number and size, the muscle layer became thicker and the fat droplets became bigger. The eosinophilic granules containing cells showed slight increase in number particularly in the site of the ligamentum latum. The C.T. especially the collagen fibres in the uterine wall decreased quickly and significantly from the 1 st day post-partum.

At the 5 - 7 day post-partum group, the number and size of fat droplets in the macrophages were slightly increased. On the other hand, the C.T, contents decreased. The eosinophilic granules containing cells appeared unevently distributed particularly in the neighbouring blood vessels. The wall of the macrophages became less clear and the nucleus replaced aside because of the increased fat droplets in the cytoplasm.

Assiut Vet. Med. J. Vol. 12, No. 24, 1984. 
MACROPHAGES IN THE UTERINE INVOLUTION

At the 9th day, the macrophages were abundant especially in myometrium, at the site of ligamentum latum. The fat droplets became bigger and occupied the main bulk of the cytoplasm, and the nucleus was pushed to a side and the cell wall became unclear. The granulated cells became scantly and the C.T. became very low. The muscle layers decreased in mass, and the uterine lumen thus regained the non-pregnant state.

\section{DISCUSSION}

The results of this study showed that early in the post-partum stages, the macrophages increased in number and were present in groups in the C.T. and between the muscle bundles. By the time, the macrophages showed further increase in number and size, a finding which agreed with that of LOBEL and DEANE (1962), PARAKKAL (1969) and DESSOUKY (1971).

The increase in the thickness of the muscle bundles at the 3 rd day was attributed to the shorten of the uterine muscle cells (ROBERTS, 1971). The decrease in the mass of the muscle layers at the 9 th day may be due to breakdown of the collagen fibres leading to decrease in the cell size (WOESSNER, 1962) or complete loss of these cells (RIESEN, SAIDUDDIN, TYLER and CASIDA, 1968).

The macrophages participated in the C.T., myometrium and endometrium engulphing and digesting the various intercellular component of the cells. Later, they underwent self-destruction by the liberation of its own hydrolytic enzymes. In rats and guinea pigs a possible enzymatic activity and lysosomal involvment in intracellular digestion by cells or autolysis of cells was indicated biochemically by WOESSNER (1965) and ultrastructurally by SCHWARZ and GULDNER (1967), BRANDES and ANTON (1969)and DESSOUKY (1971). Moreover, PARAKKAL (1969) using the electronicroscope, showed that the macrophages contained in its cytoplasm numerous vacculesfilled with collagen in vbarious stages of degradation. The long collagen fibres breaked up under the effect of collagenase enzyme into short fibres which were then capable of being taken by phagocytic cells, where they further degraded by lysosomal enzymes. The lipid droplets which appeared in the cytoplasm increased in size gradually with the advancement of purperium. The presence of these lipid granules may be due to the liberation of lipid constituents of the digested cytoplasmic membrane or might be a sign of fatty changes in the macrophages after it becomes overloaded with phagolysosome (DESSOUKY, 1971).

The macrophages took up the trypan blue in its cytoplasm by means of its phagocytic effect. BRANDES ands ANTON (1969) suggested that the overload of macrophages with lytic bodies had a deletarious effeft on the phagocytic cells due to replacement of the vital cytoplasmic organells and the release of the lytic enzymes into the cytoplasm. The rapid increase in the number of macrophages during post-partum period and the replacement of the destructed cells could be attributed either to the multipilication of the cells by mitotic activity of the resident population of the macrophages in the uterus (PARAKKAL, 1969 and DESSOUKY, 1971) or by the transformation of the monocytes into macrophages (LOBEL and DEANE, 1962 and SUTTON and WEISS, 1966).

The granulated cells which were seen mainly in the area of the ligamentum latum between the muscle layers and C.T. substance may be attributed also to regeneration form of the monocytes which seen microscopically around the B. Vs. (LOBEL and DEANE, 1962).

The main regression in the uterine wall during involution of the uterus occured in the region of ligamentum latum due to the presence of B. Vs. and abundant number of macrophages.

Assiut Vet. Med. J. Vol. 12, No. 24, 1984. 


\section{REFERENCES}

Brandes, D. and Anton, E. (1969): Cited by Parakkal (1969) J. Geront. 24 : 55.

Dessouky, D.A. (1971): Myometral changes in post-partum uterine involution. Am. J. Obst. Gyn., $110: 318$.

Lobel, B.L. and Deane, H.W. (1962): Enzymatic activity associated with post-partum involution of the uterus with its regression after withdrawal in the rat. Endocrinology, 70: 567.

Parakkal, F. (1969): Involvement of macrophages in collagen resorption. J. cell Biol, 41 : 345.

Riesen, J.W., Saiduddin, S., Tyler., W.J. and Casida, L.R. (1968): Studies on the postpartum cow. Res. Bull., 270, Univ. of Wisconsin, 27.

Roberts, S.J. (1971): Veterinary Obstetrics and Genital Diseases. 2nd Ed. Ithaca, New York.

Schwarz, W. and F.H. Guldner (19676): Elektronen mikroskopische Untersuchungen des Kollagenabbues im Uterus der Ratte mach der Schwangerschaft. Z. Zellforsch. 83 : 446.

Sutton, J.S. and L. Weiss (1966): Transformation of monocytes in tissue culture into macrophages, epitheloid cells, and multinucleated giant cells. An electron microscope study. J. cell Biol., 28: 303.

Woessner, J.F. (1962): Catabolism of collagen and non collagen protein in the rat uterus during post-partum involution. Biochem. J., 83 : 304 - 314.

Woessner, J.F. and Brewer, T. (1963): Formation and breakdown of collagen and elastine in human uterus during pregnancy and post-partum involution Biochem. J., 89 : 75.

Woessner, J.F. (1965): Uterine involution and collagen breakdown. In the structure and function of connective and skeletal tissue. S. Fitton Jackson, R.D. Harkness, S.M. Parlridge, and G.R. Tristram, editors. Butterworth, London, 442.

Assiut Vet. Med. J. Vol. 12, No. 24, 1984. 


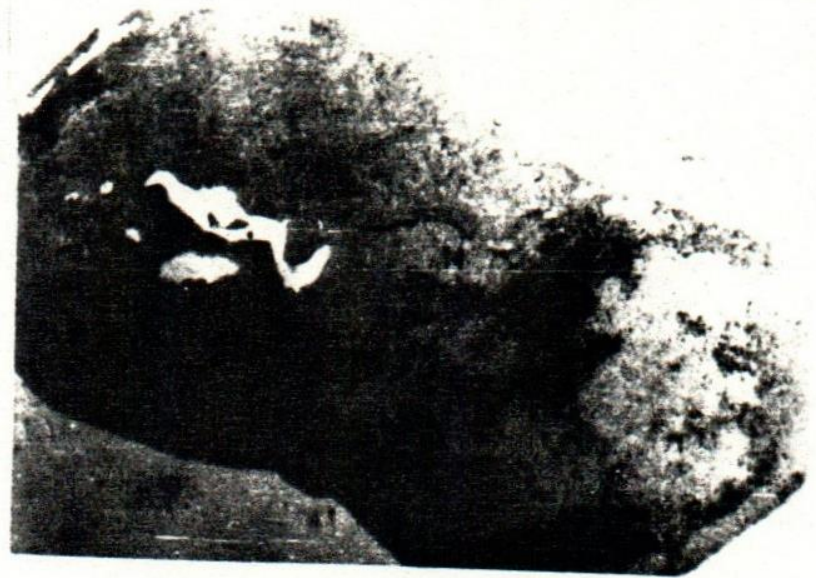

Fig. (1): $H \& E$ Stained Section of rat uterus showing the distrepution of macrophages $\times 10$

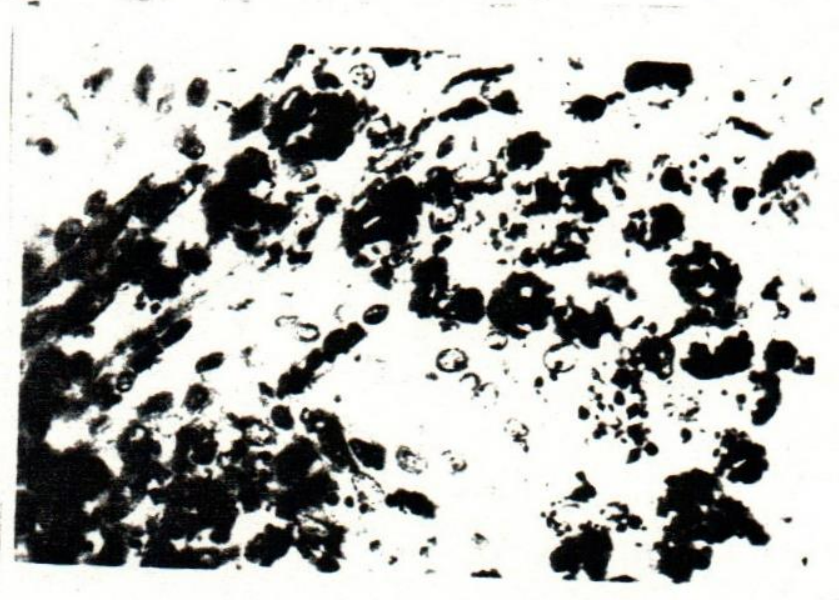

Fig. (2) $H \& E$ stained section of rat uterus showing the distribution of macrophages $\times 400$

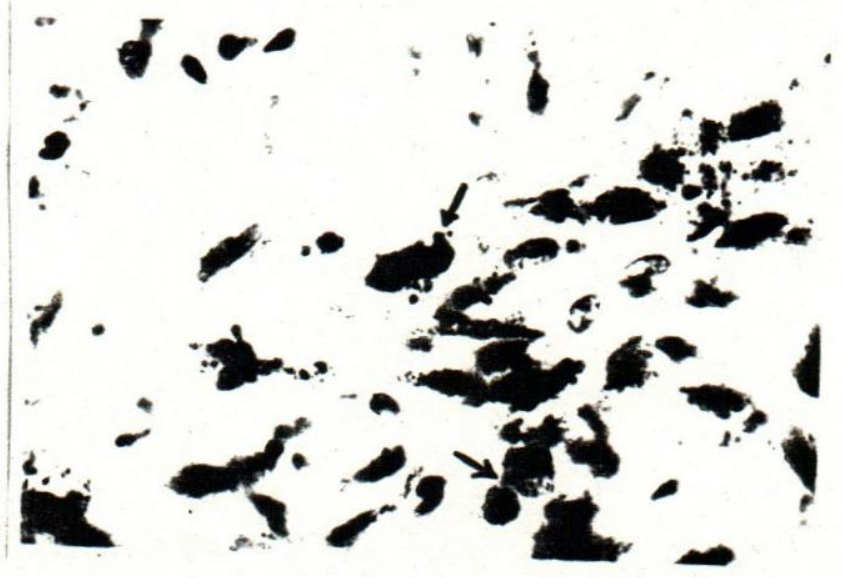

Fig- (3): Oil red 0 stained section of rat uterus showing the incidence of fat in the macrophages $\times 1000$. 
